\title{
The Effect of Temperature and Salinity on the Physiological Rates of the Mussel Perna perna (Linnaeus 1758)
}

\author{
Charrid Resgalla Jr..$^{*}$ Elisângela de Souza Brasil ${ }^{1}$ and Luis Carlos Salomão ${ }^{2}$ \\ ${ }^{I}$ CTTMar/UNIVALI; C. P. 360; cresgalla@ univali.br; 88.302-202; Itajaí - SC, Brasil. ${ }^{2}$ Instituto de Biociências; \\ Universidade de São Paulo; São Paulo - SP - Brasil
}

\begin{abstract}
The aim of this work was to study the rates of respiration, clearance, excretion and absorption efficiency at different temperature and salinity under laboratory conditions for Perna perna. Results showed variations in physiological rates and in acclimatization capacity which, taken together, enabled to understand its behavior in the environment, as well as to estimate its scope for growth. All experiments were carried out in static conditions, in ten replicas with one mussel by flasks. Perna perna was capable of achieving acclimatization for both clearance and absorption efficiency $\left(15\right.$ to $\left.30^{\circ} \mathrm{C}\right)$, but it achieved only partial acclimatization for respiration and excretion under chronic temperature conditions. The clearance and respiration rates increased twofold as the mussel was submitted to temperature shock, which signified a response to metabolism activity. Acclimatization to salinity was clearly the best developed capability (20 to $40 \%$ o). Net growth efficiency reduced as the temperature increased, but remained constant in the 20 to $35 \%$ salinity range.
\end{abstract}

Key words: Mussel, Perna perna; Physiological rates; Temperature; Salinity, Net growth efficiency

\section{INTRODUCTION}

Among the factors in the marine environment, temperature and salinity are the most important and relevant variables in the study of physiology. These variables determine the metabolism rate of the organisms and consequently, the extent of distribution of the species (Vernberg and Vernberg, 1972). A knowledge of the influence of temperature and salinity on the physiological rates of mussels is essential for the interpretation of studies on production in natural environments. In these studies of production, the energy balance of the organisms is normally investigated, known as Scope for Growth, the physiology of which responds both to variations in environmental conditions and the adverse effects of the anthropogenic agents in contaminated environments (Smaal and Widdows, 1994).

Mussels have normally been used as models of production of coastal environments and as indicators of environmental quality. The ease of laboratory work, due to their sessile behavior, size, resistance to environmental alterations and economic importance, make these the most studied invertebrate in the world. The study of the physiology of mussels under the influence of temperature has been exhaustively investigated, particularly for the species Mytilus edulis (Bayne, 1973 and 1976; Gosling, 1992; Widdows, 1973 and Widdows and Bayne, 1971), which is used as a model for the physiology of bivalves. However, there has been little investigation on the influence of salinity on the physiological rates of these organisms.

*Author for correspondence 
Perna perna is the most abundant Mytilidae on the Brazilian coast and the one which reaches the greatest size, which makes it the species of most commercial interest, and the most used in mitiliculture. There are several reports for its tolerance to variations in temperature (Bayne, 1967; Hicks and McMahon, 2002; van Erkom Schurink and Griffiths, 1992; Zuim, 1973 and 1976) and salinity (Salomão et al., 1980; Salomão and Lunetta, 1989; Zuim, 1973; Zuim and Mendes, 1980 and 1981). The aim of this work was to investigate and compare the physiological rates of the mussel Perna perna under acclimated conditions in a laboratory, to enable an understanding of its variations in reaction to temperature and salinity under constant conditions (chronic tests or routine metabolism) and thermal or saline shock (acute test or activity metabolism) investigating its acclimation capacity.

\section{MATERIALS AND METHODS}

Specimens of the mussel Perna perna were obtained between 2000/2001 from the experimental mariculture station of CTTMar where they were previously washed and selected in for size (from 3.5 to $4.5 \mathrm{~cm}$ ). The standard maintainance of the mussels consisted of acclimatizing the organisms to a salinity of $30 \%$ and a laboratory temperature of $20 \pm 2{ }^{\circ} \mathrm{C}$. Groups of 20 organisms were maintained in four-liter flasks with aeration and constant photoperiod (12 $\mathrm{h}$ light-dark cycle). Two liters of the maintenance water were renewed daily and food was inoculated (phytoplankton Chaetocerus gracilis) at a concentration of 500 Cells.mL $^{-1}$ (Resgalla Jr., 2004 and Resgalla Jr. et al., 2006) in order to establish a standard metabolism in the test organisms, eliminating seasonal variations in their metabolism.

All the groups of mussels were kept in filtered seawater $(0.5 \mu \mathrm{m})$ for $24 \mathrm{~h}$ prior to the physiological tests, in order to clean the digestive tract and stimulate their metabolic rates. The rates of respiration (RR), clearance (CR), excretion (ER) and absorption efficiency (AE) were estimated under the following test conditions:

1-Chronic Temperature Test - the RR, CR, ER and $\mathrm{AE}$ were estimated for the mussels kept at 15, 20,25 and $30{ }^{\circ} \mathrm{C}$ (constant salinity of $30 \%$ ) for a period of 15 to 20 days. The final temperature was obtained from the variation of $2.5{ }^{\circ} \mathrm{C}$ per day, based on an initial temperature of $20^{\circ} \mathrm{C}$.

2-The Acute Temperature Test - the mussels were maintained at $20{ }^{\circ} \mathrm{C}$ and $30 \%$ salinity for a period of 15 to 20 days. The RR and CR were estimated at 15,25 and $30{ }^{\circ} \mathrm{C}$ under thermal shock $24 \mathrm{~h}$ before the tests.

3-The Chronic Salinity Test - the RR, CR, ER and $\mathrm{AE}$ were estimated for the mussels maintained in salinities of $15,20,25,30,35$ and $40 \%$ (constant temperature of $20{ }^{\circ} \mathrm{C}$ ) for a period of 15 to 20 days. The final salinity was obtained by the variation of $2.5 \%$ per day, based on an initial salinity of $30 \%$.

4-The Acute Salinity Test - the mussels were maintained at $20{ }^{\circ} \mathrm{C}$ and $30 \%$ salinity for a period of 15 to 20 days. The RR and CR were estimated at salinities of $15,20,35$ and $40 \%$ under osmotic shock, $24 \mathrm{~h}$ before the tests.

\section{Clearance Rate $(\mathrm{CR})=$ Pumping Rate}

The method used consisted of estimating the rate of removal of phytoplankton (Chaetocerus gracilis) cells by the mussels, in $1000 \mathrm{~mL}$ test flasks with 10 replicas (one mussel by flask) plus two control flasks (without mussel) under static conditions (Smaal and Widdows, 1994). For each flask, concentrations of 140 Cells. $\mathrm{mL}^{-1}$ of phytoplankton and filtered seawater were inoculated for one hour. This concentration was initially established because it lower than $5 \mathrm{mg} . \mathrm{L}^{-1}$, the lowest concentration at which the rejection or formation of pseudo-feces occurs (Resgalla Jr. et al., 2006, and Widdows et al., 1979). At the start and the end of the test, with an interval of $1 \mathrm{~h}, 50$ $\mathrm{mL}$ of the seawater with phytoplankton was removed from each flask in order to determine the turbidity for absorbance in 750 and $230 \mathrm{~nm}$ through a spectrophotometer (Greenberg et al., 1992; Resgalla Jr. 2004 and Resgalla Jr. et al., 2006). The clearance rate was estimated through the application of the following equation:

$$
C R=\frac{V}{N}\left\{\left[\frac{\left(\operatorname{Ln} C_{t 0}-\operatorname{Ln} C_{t 1}\right)}{\Delta T}\right]-f\right\}
$$

where:

$\mathrm{CR}=$ Clearance rate $\left(\mathrm{L} \cdot \mathrm{h}^{-1}\right)$ 
$\mathrm{C}_{\mathrm{t} 0}=$ Initial concentration of phytoplankton (in absorbance at $750 \mathrm{~nm}$ and/or $230 \mathrm{~nm}$ )

$\mathrm{C}_{\mathrm{t} 1}=$ Concentration of phytoplankton (in absorbance at $750 \mathrm{~nm}$ and/or $230 \mathrm{~nm}$ ) at the end of the experiment.

$\mathrm{V}=$ Volume of test flask (L)

$\mathrm{N}=$ Number of organisms per test flask

$\Delta \mathrm{T}=$ Time interval of test (h)

$f=$ phytoplankton correction factor (decantation

rate) calculated using the same formula as for the control flasks.

\section{Respiration Rate (RR)}

The tests were carried out under the same conditions as previous experiments with two control flasks (without mussel) and ten test flasks with mussels, both incubated in filtered seawater without phytoplankton. The reduction in values of dissolved oxygen in the flasks was dosed using a digital oximeter (YSI Mod. 58) at the start and end of the test, and after an interval of $3 \mathrm{~h}$. The respiration rate was estimated using the equation proposed by Widdows and Johnson (1988):

$$
R R=\left[\left(C_{t 0}-C_{t 1}\right) \times \frac{V}{\Delta T}\right]-f
$$

where:

$\mathrm{RR}=$ Respiration Rate $\left(\mathrm{mLO}_{2} \cdot \mathrm{h}^{-1}\right)$.

$\mathrm{C}_{\mathrm{t} 0}=$ Concentration of oxygen at time zero $\left(\mathrm{mLO}_{2} \cdot \mathrm{L}^{-1}\right)$.

$\mathrm{C}_{\mathrm{t} 1}=$ Concentration of oxygen at the end of the experiment $\left(\mathrm{mLO}_{2} \cdot \mathrm{L}^{-1}\right)$.

$\mathrm{V}=$ Volume of test flask (L)

$\Delta \mathrm{T}=$ Time interval of incubation (h)

$f=$ Factor of correction in the control flasks obtained by the same equation.

\section{Absorption Efficiency (AE)}

The test was carried out under the same conditions as the clearance tests, but with a duration of $24 \mathrm{~h}$. The estimate proposed by Conover (1966) compared the content of the organic material present in the phytoplankton offered, with the organic material eliminated in the feces collected from the bottom of the test flask and considers the inorganic content as unaltered. The estimates were carried out according to the following equation:

$$
A E=\left[\frac{(I-F)}{1-F} \times I\right] \times 100 \%
$$

where:

$\mathrm{AE}=$ Absorption Efficiency $(\%)$

$\mathrm{I}=$ Percentage of organic material in the food offered (phytoplankton) .

$\mathrm{F}=$ Percentage of organic material in the feces.

Both the phytoplankton and the feces produced were filtered in fiberglass filters (GF/F Whatman $25 \mathrm{~mm}$ ), previously calcined and weighed. After washing with distilled water to remove the salts, the dry weight was determined by drying in an oven at $60{ }^{\circ} \mathrm{C}$ for $24 \mathrm{~h}$. The contents of the organic material were obtained by combustion of the filters in a muffle oven at $450{ }^{\circ} \mathrm{C}$ for two hours (Strickland and Parsons, 1972). To estimate the percentage of organic material of the feces produced by the mussels, each $\mathrm{CF} / \mathrm{F}$ filter concentrated feces collected from two organisms was taken from the same treatment to ensure better precision in weighing.

\section{Excretion Rate (ER)}

The tests were carried out under the same conditions as the experiments for respiration rates. At the initial and final times and at intervals of $3 \mathrm{~h}$, $15 \mathrm{~mL}$ samples of the incubation water were collected in the test flasks to determine the total amonical nitrogen, according to the colorimetric method of Strickland and Parsons (1972), modified by Baptista et al. (1987). The excretion rate was estimated according to the equation:

$$
E R=\left[\left(C_{t 1}-C_{t 0}\right) \times \frac{V}{\Delta T}\right]-f
$$

where:

$\mathrm{ER}=$ Excretion Rate $\left(\mu \mathrm{g} \mathrm{N}-\mathrm{NH}^{4+} \cdot \mathrm{h}^{-1}\right)$.

$\mathrm{C}_{\mathrm{t} 0}=$ Concentration of ammonium nitrogen at zero time.

$\mathrm{C}_{\mathrm{t} 1}=$ Concentration of ammonium nitrogen at the end of the experiment.

$\mathrm{V}=$ Volume of test flask (L)

$\Delta \mathrm{T}=$ Time interval of incubation $(\mathrm{h})$

$f=$ Factor of correction in the control flasks obtained using the same formula.

After the tests, biomass data was obtained by dissecting the organisms and their shells and drying the tissue in an oven at $60{ }^{\circ} \mathrm{C}$ for $48 \mathrm{~h}$. The specific rates for respiration, clearance and excretion were corrected for the standard weight of $1 \mathrm{~g}$ (Bayne et al., 1985) according the allometric 
correlation coefficients between weight and rate, whose respective $\mathrm{b}$ values were $0.66 ; 0.48$ and 0.91 , according to the results obtained by Resgalla Jr. (2004) and Resgalla et al. (2006). The results of the physiological rate tests for temperature and salinity were compared in variance analysis (ANOVA) and by the analysis of the Tukey test after their standardization in $\log _{10}$ (Zar, 1996).

\section{Growth efficiency}

The estimates for assimilated energy, consumed energy and net growth efficiency $\left(\mathrm{K}_{2}\right)$ were carried out using the average values for the physiological rates obtained in the chronic temperature and salinity tests, using the caloric equivalents proposed by Bayne et al. (1985) for comparisons of physiological balance in view of the variables tested. The caloric equivalents used were:

Weight or organic material of the food $=23.5$ J.mg ${ }^{-1}$

Assimilated Energy $(A)=$ Clearance rate $(C R) x$ Absorption efficiency (AE) $\mathrm{x}$ Concentration of organic material of the food in joules $\left(\mathrm{J} . \mathrm{L}^{-1}\right)$.

Respiration rate $(\mathrm{RR})=20,33 \mathrm{~J}$ per $\mathrm{mL} \mathrm{O}_{2}$ breathed.

Excretion rate $(E R)=0,0249 \mathrm{~J}$ per $\mathrm{mg} \mathrm{N}-\mathrm{NH}_{4}$ excreted.

Energy consumed $=\mathrm{RR}+\mathrm{ER}$.

Net Growth Efficiency $\left(\mathrm{K}_{2}\right)$ :

$$
K_{2}=\frac{A-(R R+E R)}{A}
$$

\section{RESULTS}

\section{Temperature}

\section{Respiration rate}

$P$. perna showed an increase in respiration rates as the temperature increased. For the chronic tests, it was observed that the rates at extreme temperatures of 15 and $30{ }^{\circ} \mathrm{C}$ were significantly different (ANOVA, $\mathrm{F}=140.22$ ), with acclimation only between 20 and $25^{\circ} \mathrm{C}$ (Fig. 1A). Under acute conditions or thermal shock, the respiration rates showed a more pronounced variation (Fig 1B), in which the rates were significantly different (ANOVA, $\mathrm{F}=81.96$ ).

\section{Clearance rate}

For the clearance rate under chronic conditions, $P$. perna showed complete acclimation, since not all the rates showed significant differences (ANOVA, $\mathrm{F}=2.17$ ) (Fig. 2A). A tendency was observed for the rate to increase with temperatures up to $25^{\circ} \mathrm{C}$, after which they decreased. This behavior was evident in the thermal shock test (Fig. 2B), in which the clearance rate was significantly higher at a temperature of $25^{\circ} \mathrm{C}$ (ANOVA, $\left.\mathrm{F}=36.96\right)$ and with inhibition at $30^{\circ} \mathrm{C}$.

\section{Excretion rate}

The excretion rate presented behavior similar to that of the respiration rate, i.e., acclimation was only observed at temperatures of 20 and $25{ }^{\circ} \mathrm{C}$ at which $P$. perna showed high excretion values for $30{ }^{\circ} \mathrm{C}$ (Fig. 3A) and significantly higher values than for the other temperatures (ANOVA, $\mathrm{F}=$ $38.01)$.

\section{Absorption efficiency \\ The variation in absorption efficiency as a result of temperature showed a total acclimation for the temperatures tested, i.e., this rate was independent of temperature since its values were significantly equal between 15 and $30^{\circ} \mathrm{C}$ (Fig. 3B) (ANOVA, F $=2.443$ ).}

\section{Salinity}

\section{Respiration Rate}

Under chronic conditions, the respiration rate presented acclimation under a wide interval of salinity (from 20 to $40 \%$ ), with a significant reduction in salinity of $15 \%$ (ANOVA, $F=14.73$ ) (Fig. 4A). Under acute conditions, the salinity interval for acclimation was reduced to 30 to $40 \%$ o (Fig. 4B), and a variation at low salinities, with a minimum of $15 \%$ and a maximum of $20 \%$ o (ANOVA, $\mathrm{F}=203.82$ ). 

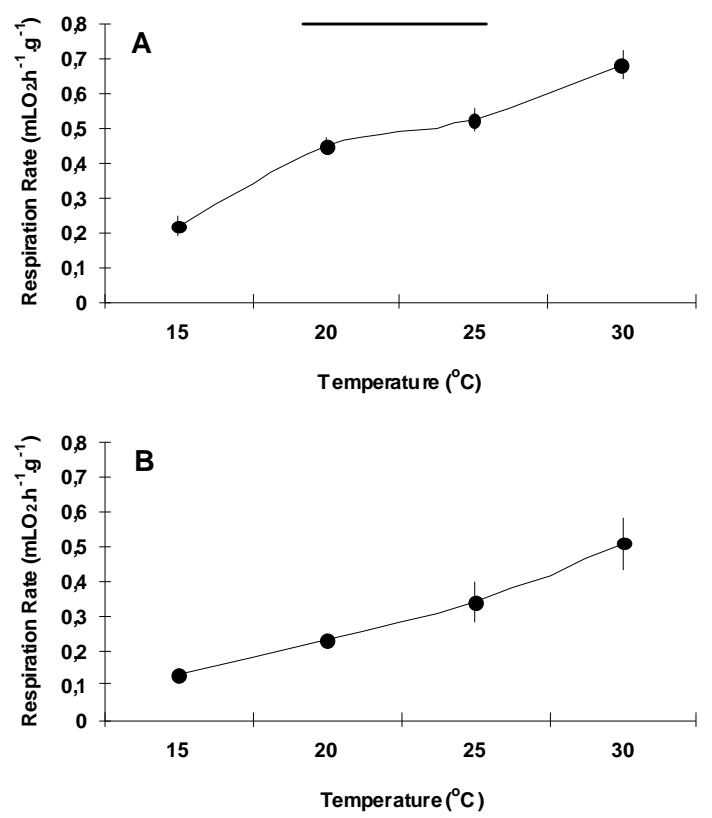

Figure 1 - Specific rates for respiration $\left(\mathrm{mL} \mathrm{O}_{2} \cdot \mathrm{h}^{-1} \cdot \mathrm{g}^{-1}\right)$ at different temperatures. (A) Chronic test (constant temperature) and (B) Acute test (thermal shock after acclimation at $20{ }^{\circ} \mathrm{C}$ ) for mussel the Perna perna. Average values and confidence interval of $95 \%$. The bars indicate the rates significantly similar according to the Tukey test.
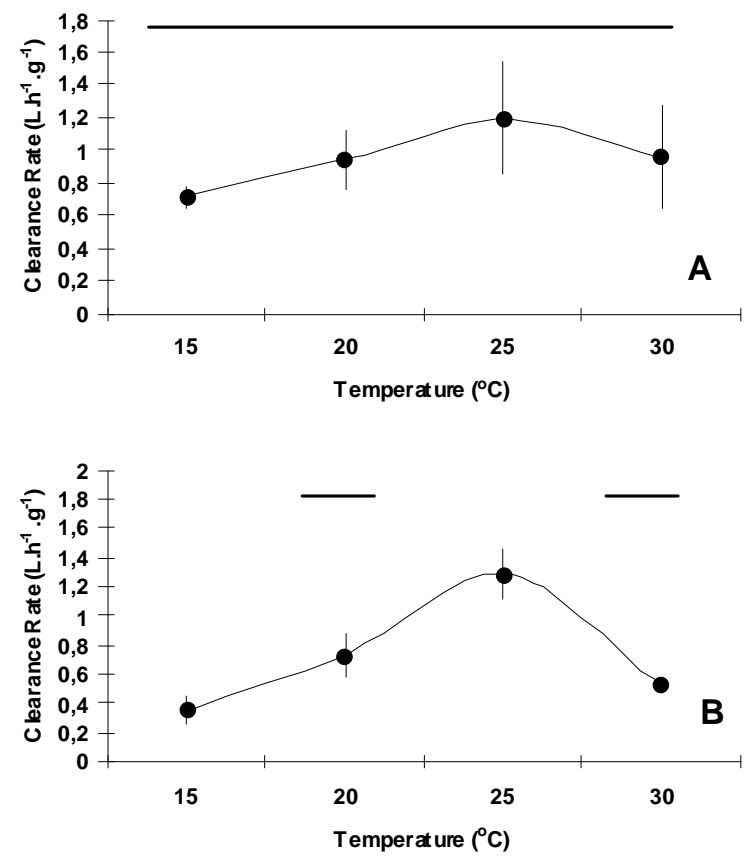

Figure 2 - Specific rates for clearance $\left(L \cdot h^{-1} \cdot g^{-1}\right)$ at different temperatures. (A) Chronic test (constant temperature) and (B) Acute test (thermal shock after acclimation at $20{ }^{\circ} \mathrm{C}$ ) for mussel the Perna perna. Average values and confidence interval of $95 \%$. The bars indicate the rates significantly similar according to the Tukey test. 


\section{Clearance rate}

Similar to the respiration rate, the clearance for $P$. perna showed a wide band of acclimation to salinity (from 20 to $40 \%$ ) with a significant inhibition at $15 \%$ (ANOVA, $\mathrm{F}=15.99$ ) (Fig. 5A). Under osmotic shock (Fig. 5B), the acclimation interval was reduced to 20 to $35 \%$ with significant inhibitions at 15 and $40 \%$ (ANOVA, F $=50.66)$.

\section{Excretion rate}

For the excretion rate, $P$. perna presented two separate acclimation intervals under acute conditions (ANOVA, F = 13.05). The first was characterized by low rates, or inhibition of excretion between salinities of 15 to $25 \%$ and the second by higher rates of between 30 and $40 \%$ 。 (Fig. 6A).

\section{Absorption efficiency}

In acute conditions, the absorption efficiency presented a wide band of acclimation, which included salinities of 20 to $35 \%$ (Fig. 6B), with significant inhibition for the extreme salinities of 15 and $40 \%$ (ANOVA, $F=10.80$ ).

\section{DISCUSSION}

In this work, the existence of compensation capacity of $P$. perna was determined to variations in temperature and salinity. Initially, the acclimation capacity was evaluated after 15 days, the time required to enter a state of routine metabolism (Resgalla Jr. et al., 2006) and demonstrate physiological compensations to the variations in temperature and salinity, i.e. to present the same routine metabolism, irrespective of the treatment administered.
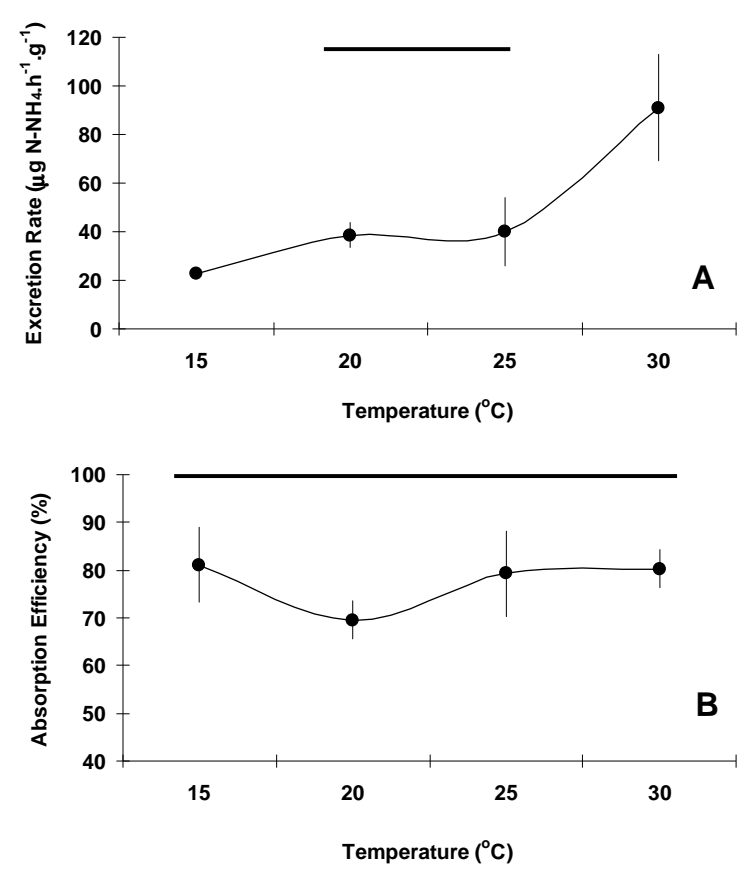

Figure 3 - (A) Specific excretion rates (mg N-NH4.h $\left.{ }^{-1} \cdot \mathrm{g}^{-1}\right)$ and (B) absorption efficiencies (\%) in chronic tests (constant temperature) for the mussel Perna perna. Average values and confidence interval of $95 \%$. The bars indicate the rates significantly similar according to the Tukey test. 

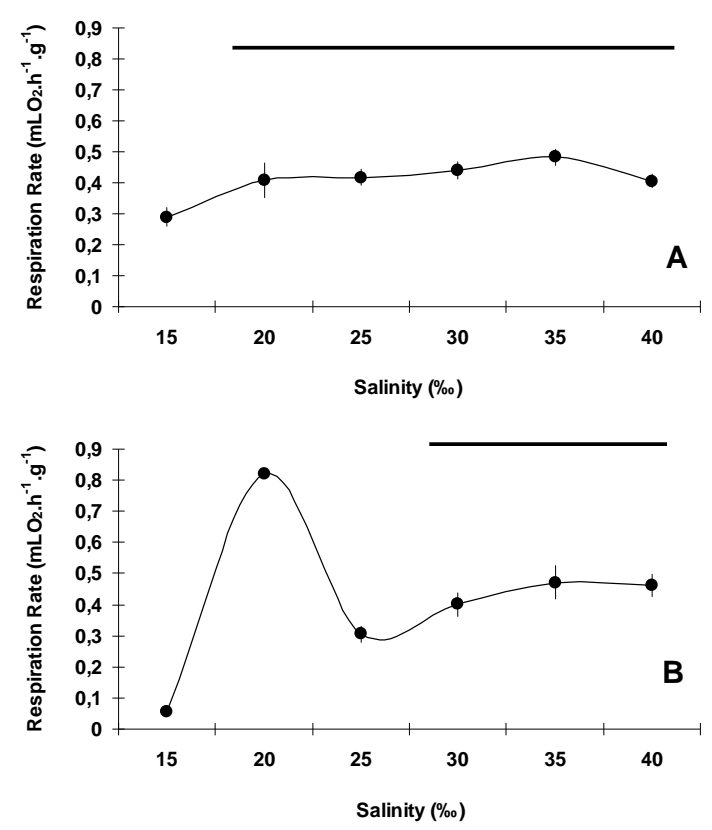

Figure 4 - Specific rates of respiration (mL O2.h-1.g-1) at different salinities. (A) Chronic test (constant salinity) and (B) Acute test (osmotic shock after acclimation at $30 \%$ ) for the mussel Perna perna. Average values and confidence interval of 95\%. The bars indicate the rates significantly similar according to the Tukey test.
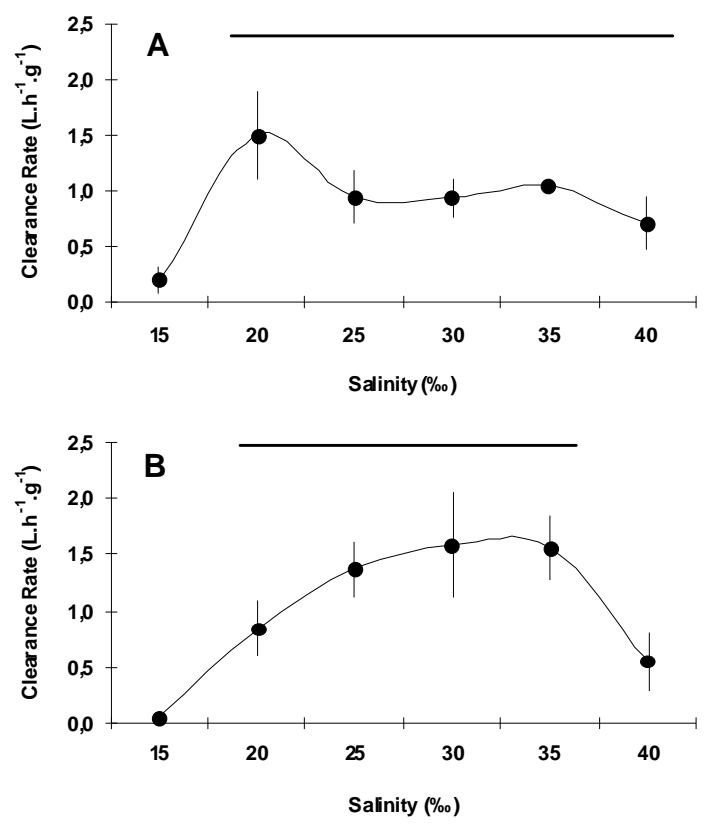

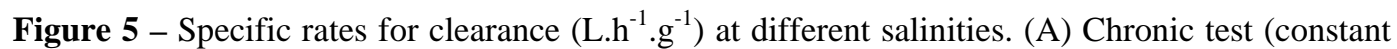
salinity) and (B) Acute test (osmotic shock after acclimation at $30 \%$ ) for the mussel Perna perna. Average values and confidence interval of $95 \%$. The bars indicate the rates significantly similar according to the Tukey test. 

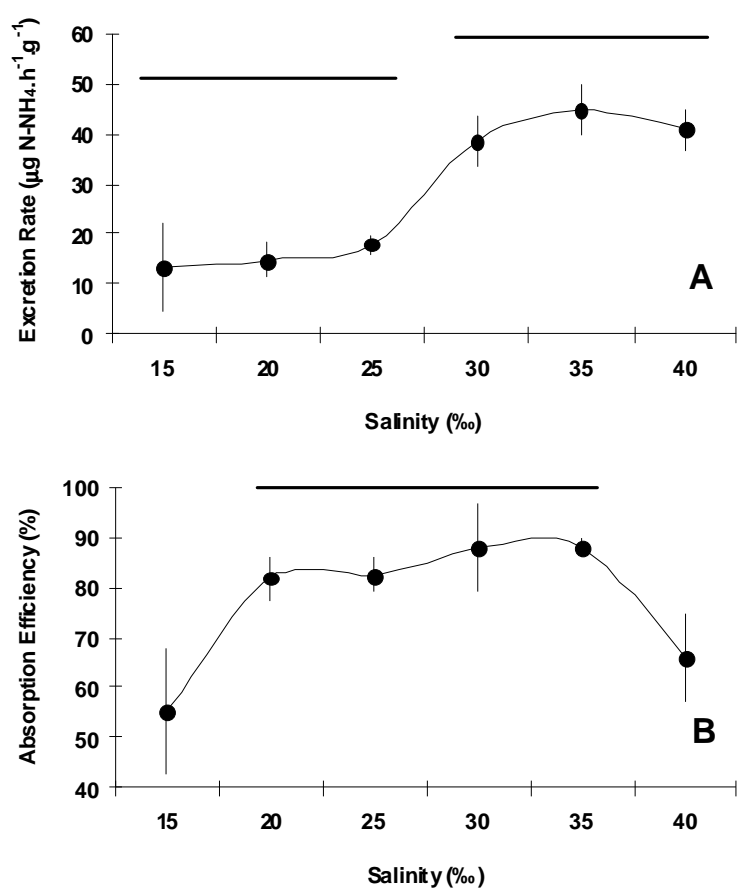

Figure 6 - (A) Specific excretion rates $\left(\mathrm{mg} \mathrm{N}-\mathrm{NH}_{4} \cdot \mathrm{h}^{-1} \cdot \mathrm{g}^{-1}\right)$ and (B) absorption efficiencies (\%) in chronic tests (constant salinity) for the mussel Perna perna. Average values and confidence interval of $95 \%$. The bars indicate the rates significantly similar according to the Tukey test.

Subsequently, the potential activity of the organisms submitted to acute shocks was investigated, following an acclimation period, with the aim of causing the metabolism to leave routine state and enter a state of activity or standard metabolism, depending on the occurrence of increase or decrease in the physiological rates tested (Bayne, 1973 and Widdows, 1973). With this, it is possible to determine the level at which the activity of the organism can reach, since the activity metabolism cannot be maintained for a long period of time, before returning to the routine metabolism (Bayne et al., 1973).

\section{Temperature}

Temperature is recognized as one of the major factors influencing the respiration rates and energy balance of poikilothermal marine organisms. Various authors have highlighted the fact that the respiration rates of bivalves are dependant on temperature, be they in acute or chronic conditions (Bayne and Newell, 1985; Griffiths and Griffiths, 1987 and Widdows, 1973, 1976, 1978). Some compensatory adjustment is to be expected in organisms in terms of energy balance, to minimize the losses. In fact, acclimation of the organisms occurs, but its amplitude can vary as a result of the species and geographical distribution. Widdows (1973) found that a temperature of $20^{\circ} \mathrm{C}$ was the limit of tolerance of Mytilus edulis, with an independent metabolism at temperatures below this and dependence above this limit (Bayne and Thompson, 1970 and Bayne et al., 1973).

Under acute conditions, $P$. perna presented a partial acclimatization of respiration rates between 20 and $25^{\circ} \mathrm{C}$. Between 15 and $30^{\circ} \mathrm{C}$, P. perna had not demonstrate this compensation capacity, whether in chronic or acute conditions.

For acute conditions, $P$. perna changed its routine metabolism to the activity metabolism between 20 and $30^{\circ} \mathrm{C}$, with a 2.22 -fold increase in respiration rates. This meants $\mathrm{Q}_{10}$ values higher than 2 obtained for this interval (Table 1). Other authors presented different $\mathrm{Q}_{10}$ values for $P$. perna in different maintenance conditions (Table 1), in which the thermo-independence $\left(\mathrm{Q}_{10}<2\right)$ varied greatly as a result of the interval considered. The results obtained in this work was close to those 
obtained by Hicks and McMahon (2002). Some authors highlighted that the inhibition of the respiration rate based on a maximum temperature was known as the lethal temperature. According to Zuim (1973), the lethal temperature of the species from the coast of São Paulo was $40{ }^{\circ} \mathrm{C}$. Hicks and McMahon (2002) showed that the lethal temperature of P.perna from the Gulf of México was $30^{\circ} \mathrm{C}$. In this work, despite the fact that no inhibition in respiration rates was observed, it was observed that the organisms acclimated to $30{ }^{\circ} \mathrm{C}$ did not present the capacity to form byssus, a characteristic which was used as an indicator of stress in mussels (Bayne, 1976).

In an inverse situation, under negative thermal shock (from 20 to $15^{\circ} \mathrm{C}$ ), P. perna switched from routine to standard metabolism, with an approximately two-fold reduction in respiration rates, both in acute and chronic conditions. Thompson and Bayne (1972) and Widdows, (1973) highlighted the existence of a respiration rate in which no pumping of water by the organism occurred, which was considered to be the standard rate of metabolism. This rate was obtained by the interpolation of a regression between these two variables and the estimated value for $P$. perna was $0.099 \mathrm{~mL} \mathrm{O} \cdot \mathrm{h}^{-1} \cdot \mathrm{g}^{-1}$, i.e., close to the respiration rate at $15^{\circ} \mathrm{C}$.

For the clearance rates, the results were similar to those obtained by Widdows (1973 and 1976) for M. edulis. For this species, Widdows (1978) highlighted that at temperatures of above $20^{\circ} \mathrm{C}$, the clearance rate suffered inhibition. Griffiths and Griffiths (1987) emphasized that the maximum clearance rate was known as the optimum rate and was dependant on the acclimation temperature of the organism. According to these authors, the optimum rate for the oyster Ostrea edulis occurred at $5{ }^{\circ} \mathrm{C}$ above the acclimation temperature. $P$. perna presented this inhibition only in acute conditions and the maximum rate was also $5{ }^{\circ} \mathrm{C}$ above the acclimatization temperature. But in chronic conditions, its acclimatization was total, despite showing the same tendency to vary with temperature.

The excretion rate has been used as an indicator of stress of the organism (Smaal and Widdows, 1994), and it increases with temperature due to the metabolic energy demand in M. edulis (Griffiths and Griffiths, 1987 and Widdows, 1978). In this work, the excretion rate presented acclimation only for the 20 to $25^{\circ} \mathrm{C}$ interval, with maximum at 30 and minimum at $15^{\circ} \mathrm{C}$.

The relation between absorption efficiency and temperature presents conflicting results among authors. According to Griffiths and Griffiths (1987), filtrating bivalves can show from a relation of independence through to an increase or decrease in efficiency with increase in temperature. For Widdows (1978), the absorption efficiency of Mytilus edulis was independent of temperature, but even for this species, this relation can vary from one author to another (Griffiths and Griffiths, 1987).

Table $1-\mathrm{Q}_{10}$ Values obtained for Perna perna based on its respiration rates in different temperatures obtained from different authors.

\begin{tabular}{|c|c|c|c|c|c|c|}
\hline & $\begin{array}{l}\text { Temperature } \\
\text { Interval }\end{array}$ & This work & $\begin{array}{l}\text { Bayne } \\
(1967)\end{array}$ & $\begin{array}{c}\text { Berry and } \\
\text { Schleyer }(\mathbf{1 9 8 3})\end{array}$ & $\begin{array}{c}\text { van Erkom } \\
\text { and Griffiths } \\
(1992)\end{array}$ & $\begin{array}{c}\text { Hicks and } \\
\text { McMahon } \\
(2002) \\
\end{array}$ \\
\hline \multirow{3}{*}{ Chronic } & $15-20$ & 4.29 & & & & \\
\hline & $20-25$ & 1.37 & & & & \\
\hline & $25-30$ & 1.69 & & & & \\
\hline \multirow{5}{*}{ Acute } & $10-15$ & & & & 1.56 & 3.55 \\
\hline & $15-20$ & 3.12 & 1.28 & 2.04 & 2.37 & 1.31 \\
\hline & $20-25$ & 2.16 & 1.20 & 1.74 & & 2.24 \\
\hline & $25-30$ & 2.20 & 1.49 & & & 1.43 \\
\hline & $30-35$ & & 2.64 & & & \\
\hline
\end{tabular}

In this work, $P$. perna showed independence of temperature for the interval between 15 and $30{ }^{\circ} \mathrm{C}$. According to Bayne and Newell (1983), the absorption efficiency depends on the length of time the food remains in the digestive tract and the rate of intake. In other words, there is a balance 
between clearance rate and absorption efficiency. This highlights the independence of clearance and absorption rates in relation to acclimation temperature (Figs. 5A and 6B).

\section{Salinity}

Little information is known about the variation of physiological rates of mussels under conditions of different salinities. The common reaction of bivalves to alterations in salinity is a reduction in functional activity (Berger and Kharazova, 1997) and a closing of the valves, which enables a low rate of loss of salts to the perivisceral fluid and survival for up to two days (Salomão et al., 1980). It is generally known that the respiration rate decreases with the decrease in salinity (Griffiths and Griffiths, 1987). This was also observed by Bayne (1967) for P. perna, and was classified as stenohaline. Zuim (1973) and Zuim and Mendes (1981), P. perna presented low respiration rates in salinities below $24 \%$. In this work, $P$. perna showed ample acclimatization to different salinities in the chronic tests, presenting inhibition of respiration rates only for salinities of $15 \%$. In acute situations, the oscillations in respiration rates probably reflect compensatory mechanisms which the organism is able to release in situations of hyposmotic shock, in an attempt to keep the blood hyperosmotic (Gilles, 1982).

Just as observed for the respiration rates, $P$. perna showed ample acclimation capacity for the clearance rate and for the absorption efficiency in different salinities, showing inhibition only at the extremes of 15 and $40 \%$ o. Bayne (1976) found an inhibition in clearance rates in high salinities for M. edulis, while Navarro (1988) observed the same inhibition but in low salinities for Mytilidae Cloromytilus clorus as well as independence of absorption efficiency from salinity. Navarro and Gonzalez (1998), in a study with the scallop Argopecten purpuratus, observed similar results to those obtained in this work for the clearance rate and absorption efficiency.

For the excretion rates, however, the results obtained in this work were not in agreement with the majority of works on other species of filtrating bivalves. Normally, excretion rates increase with the decrease in salinity (Navarro and Gonzalez, 1998 and Griffiths and Griffiths, 1987) and these are also used as indicators of metabolic stress. In this work, the excretion rates were inhibited in low salinities $(<25 \%$ o). Mollusks are osmoconformers, i.e. the blood is in osmotic equilibrium with the external fluid. This capacity is provided by inorganic and organic osmotic effectors (Gilles, 1982). The inorganic effectors have been studied by Salomão and Lunetta (1989), who showed that the osmotic equilibrium of the hemolimph was established at $72 \mathrm{~h}$ with the highest concentration of $\mathrm{K}$ and $\mathrm{Ca}$ ions. But the most important effectors are organic, particularly free amino acids, whose concentration is regulated by the enzyme aminopeptidase-1 (Newell, 1989). According to Griffiths and Griffiths (1987), the highest excretion rates observed in mussels exposed to low salinities (or hyposmotic shocks) are the result of elimination and breaking down of these amino acids by the cells (Bayne and Newell, 1983; Navarro and Gonzalez, 1998 and Newell, 1989). However, Gilles (1981) highlights that a second destination for these amino acids would be the formation of proteic material in the blood and that they may present a lesser effect on osmolality, perhaps serving as a source of amino acids in case of hyperosmotic shocks. This process would be more economic for the organism, since it requires only $16 \%$ of the energy of the basal metabolism (Hawkins, 1985) and would make raw material available for the proteic catabolism. On the other hand, Navarro (1988) obtained inhibition in excretion rates for the mussel Choromutilus chorus, justifying its results as an product of the closure of the valves and inhibition of excretion by an accumulation of ammonium in the visceral liquid.

\section{O:N Ratio}

The O:N ratios were compared as an indicator of the nutritional conditions of the organisms. According to Bayne and Thompson (1970), a prevalence of catabolism of carbohydrates and lipids results in values higher than 30 , while a protein catabolism (conditions of alimentary deficiency) results in values of less than 30 . Initially, all conditions of maintenance showed a prevalence of protein catabolism (Fig. 7) due to maintenance conditions in which the quantity of food was not sufficient for the needs of the organism (Resgalla Jr. 2004 and Resgalla Jr. et al. in press). However, for the temperature tests, the values for the $\mathrm{O}: \mathrm{N}$ ratio were significantly higher at $25{ }^{\circ} \mathrm{C}$ (ANOVA, $\mathrm{F}=25.652$ ) than at the other temperatures, and close to 30 , indicating an optimum maintenance temperature.

On the other hand, for the tests in low salinities,(between 15 and $25 \%$ ), the values of the 
ratio were higher than 30 and significantly different from the other salinities (ANOVA, F=

24.051).
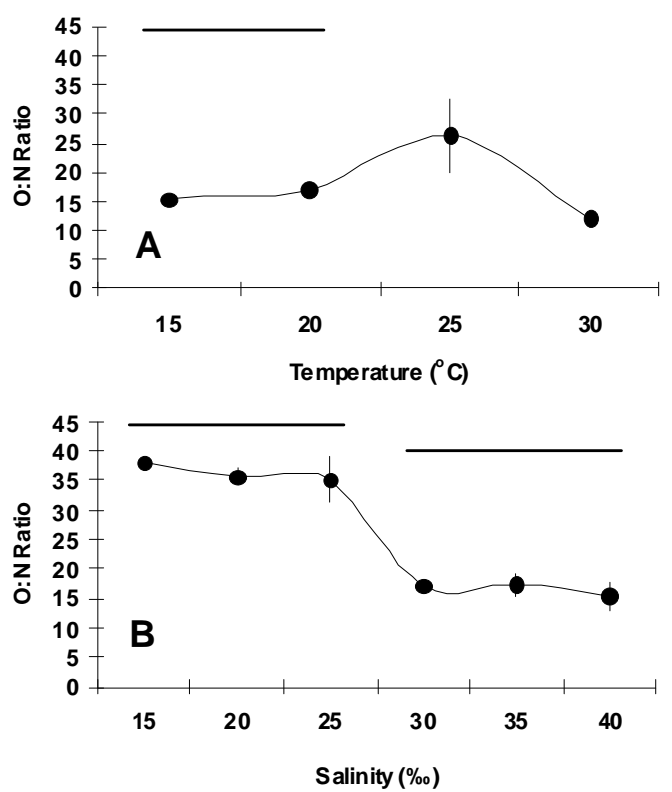

Figure 7 - O:N Ratios (A) at different temperatures and (B) at different salinities obtained in chronic tests for the mussel Perna perna. Average values and confidence interval of $95 \%$. The bars indicate the rates significantly similar according to the Tukey test.
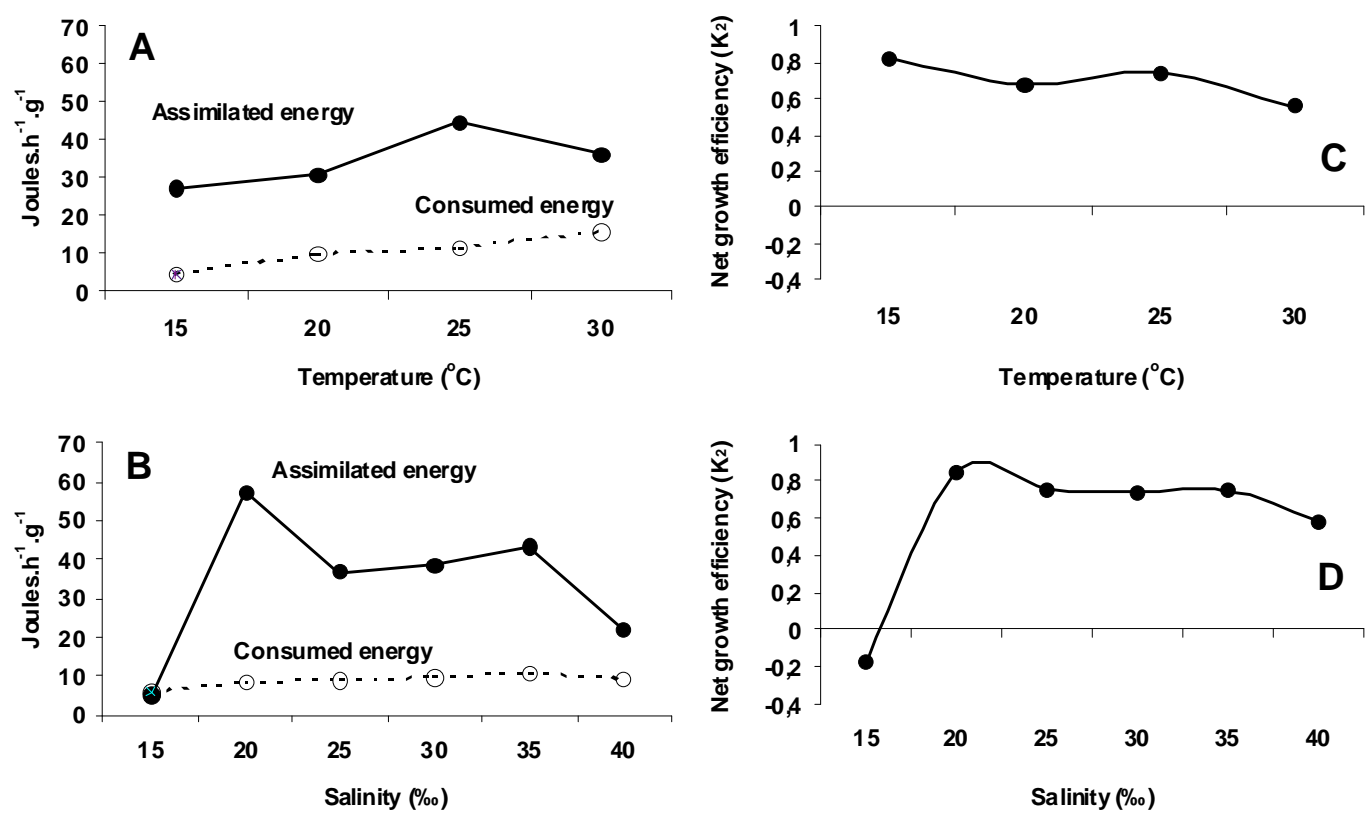

Figure 8 - Variations in assimilated energy, consumed energy $\left(\mathrm{J} \cdot \mathrm{h}^{-1} \cdot \mathrm{g}^{-1}\right)$ (A e B) and net growth efficiency $\left(\mathrm{K}_{2}\right)(\mathrm{C}$ and $\mathrm{D})$ of the mussel Perna perna at different temperatures and salinities of acclimation (chronic tests). 
In this case, the O:N ratio presented false results and loses its power to be used as an indicator of stress since in low salinities the inhibition of excretion rates occured.

\section{Energy balance and net growth efficiency.}

$P$. perna presents acclimatization for the interval of 20 to $25{ }^{\circ} \mathrm{C}$, with $25{ }^{\circ} \mathrm{C}$ being the optimum temperature due to the higher clearance rates in acute conditions (obtainance of energy for metabolism) (Fig. 8). At $15{ }^{\circ} \mathrm{C} \mathrm{P}$. perna presented a partial, but acceptable, acclimation capacity, since the positive balance of energy was possible due to the low respiration and excretion rates. At $30{ }^{\circ} \mathrm{C}$, the mussel would be in conditions of stress, which could jeopardize its survival due to the higher respiration and excretion rates, resulting in a higher energy expense. According Zuim (1976), the medium lethal time $\left(\mathrm{LT}_{50}\right)$ of $P$. perna submitted to thermic shock at $30{ }^{\circ} \mathrm{C}$ would be 2.2 days. The survival of P.perna in a laboratory at 30 ${ }^{\circ} \mathrm{C}$ was due to its slow acclimation $\left(2.5^{\circ} \mathrm{C}\right.$.day $\left.{ }^{-1}\right)$, which enables the development of Heat Shock Proteins (HSP), given that the sensitivity of their expression is dependant on the thermal history of the organism (Feder and Hofmann, 1999). The sign which triggers the production of HSP is the concentration of abnormal proteins in the cell, occasioned, among other factors, by variations in temperature (Hofmann et al., 2002). This fact gives the organisms resistance to the maintenance conditions at temperature extremes. Thus, there was a tendency towards a decrease in net growth efficiency of $P$. perna with the increase in temperature caused primarily by the increase in energy expenditure including biochemical compensatory mechanisms.

For salinity, the amplitude of acclimation was higher (from 20 to $35 \%$ ), the net growth rate being negative for $15 \%$ and reduced for $40 \%$ (Fig. 8). Contrary to temperature, these negative growth are due not to energy expenditure, but to the inhibition of energy assimilated by the organism.

In general, $P$. perna presented a higher acclimation capacity for salinity than for temperature variations, both for chronic and acute conditions. There is no doubt that $P$. perna is a euryhaline and eurythermic species. Temperature strongly influences the respiration rates (direct relation) and the excretion rates above $25{ }^{\circ} \mathrm{C}$. Salinity proved to have a strong influence on clearance rates, which are inhibited at low salinities $(<25 \%)$.

\section{ACKNOWLEDGEMENTS}

The authors are thankful to Adriano Marenzi and Gilberto Manzoni for help with the mussel support, CAPES - National Council for Science and Technological Development for the Ph.D fellowship and UNIVALI - University of Vale do Itajaí for funding provision.

\section{RESUMO}

O molusco bivalve Perna perna é o Mytilidae de maior tamanho e o mais abundante na costa brasileira. Apresenta uma grande importância sócio-econômica devido ao seu uso na mitilicultura, disponibilizando para o consumo humano uma fonte protéica barata proporcionado pelos sistemas de cultivos costeiros. Entretanto, existe uma carência de estudos fisiológicos da espécie, que poderiam ser úteis na avaliação de novas áreas de cultivo, assim como no monitoramento de ambientes contaminados. Neste trabalho foram realizadas testes fisiológicos para determinar as taxas de respiração, clareamento, excreção e eficiência de absorção em laboratório, sob condições crônicas e agudas, em diferentes temperaturas e salinidades. Desta forma, foi possível determinar as oscilações e a capacidade de aclimatação da espécie que servem como base para o entendimento do organismo no ambiente natural, além de gerar conhecimento básico para estimativas do seu potencial de crescimento. Todos os experimentos foram realizados em condições estáticas com dez réplicas e com um mexilhão por frasco teste. A taxa de respiração foi estimada pela diminuição do oxigênio dissolvido na água de incubação, a taxa de clareamento pela diminuição da concentração do fitoplâncton oferecido como alimento, a taxa de excreção pelo aumento da concentração do $\mathrm{N}-\mathrm{NH}^{4+}$ e a eficiência de absorção pela diferença entre os conteúdos de matéria orgânica do alimento e das fezes produzidas. Perna perna apresentou capacidade de aclimatação total para as taxas de clareamento e para a eficiência de absorção $\left(15\right.$ a $\left.30^{\circ} \mathrm{C}\right)$ e parcial para as taxas de respiração e excreção sob 
condições crônicas de temperatura. Em condições de choque térmico, as taxas de clareamento e respiração dobraram em magnitude como resposta ao metabolismo de atividade. Para a salinidade, $P$. perna apresentou uma maior capacidade de aclimatação (20 a $40 \%$ \%). Para o crescimento líquido, $P$. perna apresentou uma diminuição de sua eficiência com o aumento da temperatura e foi constante entre as salinidades de 20 a $35 \%$.

\section{REFERENCES}

Baptista, J. M. R.; Baumgarten, M. G. Z. and Niencheski, L. F. H. (1987), Caderno de análises em oceanografia química. Documento N. 8. Editora da FURG

Bayne, B. L. (1967), The respiratory response of Mytilus perna L. (Mollusca: Lamellibranchia) to reduced environmental oxygen. Physiological Zoology, 40:307-313

Bayne, B. L. (1973), Physiological changes in Mytilus edulis L. induced by temperature and nutritive stress. J. Mar. Biol. Ass. U.K., 53: 39-58

Bayne, B. L. (1976), Marine mussels: their ecology and physiology. Cambridge University Press. London

Bayne, B. L.; Brown, D. A.; Burns, K.; Dixon, D. R.; Ivanovici, A.; Livingstone, D. R.; Lowe, D. M.; Moore, M. N.; Stebbing, A. R. D. and Widdows, J. (1985), The effects of stress and pollution on marine animals. Praegez Publshers, New York

Bayne, B. L. and Newell, R. C. (1983), Physiological energetics of marine molluscs. In-The mollusca. V4 Physiology Parte 1, eds. Salevddin, A. S. M. and Wilbur, K. M. Academic Press. New York, pp. 407515

Bayne, B. L. and Thompson, R. J. (1970), Some physiological consequences of keeping Mytilus edulis in the laboratory. Helgoländer wiss. Meeressunters, 20:526-552.

Bayne, B. L.; Thompson, R. J. and Widdows, J. (1973), Some effects of temperature and food on the rate of oxygen consumption by Mytilus edulis L. In-Effects of temperature on ectothermic organisms, ed. W. Wieser. Springer-Verlag, Berlim. pp. 181-193

Berger, V. J. and Kharazova, A. D. (1997), Mechanisms of salinity adaptations in marine molluscs. Hydrobiologia, 355: 115-126

Berry, P. F. and Schleyer, M. H. (1983), The brown mussel Perna perna on the Natal coast, South Africa: Utilization of available food and energy budget. Mar. Ecol. Progr. Series, 13:201-210

Conover, R. J. (1966), Assimilation of organic matter by zooplankton. Limnol. Oceanogr., 11:338-345.
Feder, M. E. and Hofmann, G. E. (1999), Heat-Shock proteins, molecular chaperones, and the stress response: evolutionary and ecological physiology. Annu. Rev. Physiol., 61:243-282

Gilles, R. (1982), Osmoregulatory process in mollusks and crustaceans from media with fluctuating salinity regime. Bol. Fisiol. Animal. USP., 6:1-36

Gosling, E. (1992), The mussel Mytilus edulis: Ecology, Physiology, Genetics and Culture. Elsevier. Amsterdam

Greenberg, A. E.; Clesceri, L. S. and Eaton, A. D. (1992), Standard methods for the examination of water and wastewater. $18^{\text {th }}$ edition, APHA, Washington

Griffiths, C. L. and Griffiths, R. J. (1987), Bivalvia. InAnimal energetics. Vol. 2 Bivalvia through Reptilia eds. Pandian, T. J. and Vernberg, F. J. Academic Press. New York. pp 1-88

Hawkins, A. J. S. (1985), Relationships between the synthesis and breakdown of protein, dietary absorption and turnovers and carbon in the blue mussel, Mytilus edulis L. Oecologia, 66:42-49

Hicks, D. W. and McMahon, R. F. (2002), Respiratory responses to temperature and hypoxia in the noindigenous brown mussel Perna perna (Bivlavia: Mytilidae), from the Gulf of Mexico. J. Exp. Mar. Biol. Ecol., 277:61-78

Hofmann, G. E.; Buckley, B. A.; Place, S. P. and Zippay, M. L. (2002), Molecular chaperones in ectothermic marine animals: biochemical function and gene expression. Integ. and Comp. Biol., 42: 808814

Navarro, J. M. (1988), The effects of salinity on the physiological ecology of Cloromytilus clorus (Molina, 1782) (Bivalvia: Mytilidae). J. Exp. Mar. Biol. Ecol., 122: 19-33

Navarro, J. M. and Gonzalez, C. M. (1998), Physiological responses of the Chilean scallop Argopecten purpuratus to decreasing salinities. Aquaculture, 167:315-327

Newell, R. I. E. (1989), Species profiles: life histories and environmental requirements of coastal fishes and invertebrates (north and mid Atlantic). Blue mussel. U.S. Fish. Wildl. Serv. Biol. Rep. 82(11.102). U.S. Army Corps of Engineers, TR EL-82-4

Resgalla Jr. C. (2004), Taxas fisiológicas e potencial de crescimento do mexilhão de cultivo Perna perna (L.). PhD Thesis, IB-USP

Resgalla Jr. C., E. S. Brasil and Salomão, L. C. (2006), Physiological rates in different classes of sizes of Perna perna (Linnaeus, 1758) submitted to experimental laboratory conditions. Braz. J. Biol., 66(1b):325-336

Salomão, L. C. and Lunetta, J. E. (1989), The effects of salinity changes on the osmotic ionic concentrations in the hemolymph of Perna perna (Mollusca: Bivalvia). Bol. Fisiol. Animal. USP, 13: 29-38 
Salomão, L. C., A. R. M. Magalhães and Lunetta, J. E. (1980), Influência da salinidade na sobrevivência de Perna perna (Mollusca: Bivalvia). Bol. Fisiol. Animal. USP, 4:143-152

Smaal, A. C. and Widdows, J. (1994), The scope for growth of bivalves as an integrated response parameter in biological monitoring. In-Biomonitoring of coastal waters and estuaries. Ed. Kramer, K.J.M. Chapter 2. CRC Boca Raton

Strickland, J. D. H. and Parsons, T. R. (1972), A practical handbook of seawater analysis, Bull. Fish. Res. Bd. Canada.

Thompson, R. J. and Bayne, B. L. (1972), Active metabolism associated with feeding in the mussel Mytilus edulis L. J. Exp. Mar. Biol. Ecol., 9:111-124

Van Erkom Schurink, C. and Griffiths, C. L. (1992), Physiological energetics of four South African mussel species in relation to body size, ration and temperature. Comp. Biochem. Physiol., 101A(4):779789

Vernberg, W. B. and Vernberg, F. J. (1972), Environmental physiology of marine animals. Springer-Verlag, Berlin

Widdows, J. (1973), The effects of temperature on the metabolism and activity of Mytilus edulis. Netherlands J. Sea Res., 7:387-398

Widdows, J. (1976), Physiological adaptation of Mytilus edulis to cyclic temperatures. J. Comp. Physiol., 105:115-128

Widdows, J. (1978), Combined effects of body size, food concentration and season on the physiology of Mytilus edulis. J. Mar. Ass. U.K., 58:109-124

Widdows, J. and Bayne, B. L. (1971), Temperature acclimatization of Mytilus edulis with reference to its energy budget. F. Mar. Biol. Ass. U.K., 51: 827-843
Widdows, J.; Fieth, P. and Worrall, C. M. (1979), Relationships between seston, available food and feeding activity in the common mussel Mytilus edulis. Mar. Biol., 50:195-207

Widdows, J. and Johnson, D. (1988), Physiological energetics of Mutilus edulis: Scope for growth. Mar. Ecol. Progr. Series, 46:113-121

Zar, J. H. (1996), Biostatistical analysis. Prentice Hall, New Jersey

Zuim, S. M. F. (1973), Metabolismo respiratório de dois moluscos bivalvos tropicais: influência de fatores intrínsecos e ambientais. MSc. Thesis. IBUSP

Zuim, S. M. F. (1976), Metabolismo respiratório e tolerância de Brachidontes solisianus (d' Orginy, 1846) e Perna perna (Linné, 1758) - Mollusca bivalvia Mytilidae - Influências da temperatura, tensão de oxigênio e exposição ao ar. $\mathrm{PhD}$. Thesis. IB-USP

Zuim, S. M. F. and Mendes, E. G. (1980), Tolerância de Perna perna e Brachidontes solisianus a diferentes salinidades. Rev. Bras. Biol., 40(1):137-141

Zuim, S. M. F. and Mendes, E. G. (1981), A influência da salinidade na taxa respiratória de dois mexilhões, Perna perna e Brachidontes solisianus (Mollusca: Bivalvia). Rev. Bras. Biol., 41(1):57-61

Received: July 11, 2005; Revised: March 02, 2006; Accepted: March 09, 2007. 